a parade with floats carrying the slogans "Who Sabatoged Three Mile Island?" and "Uranium for Our Children", New Mexico Senator Harrison Schmidt told the rally:

"I will do everything in my legislative power to eliminate the need for environmental impact statements for future uranium mines and mills."

And in the meantime, in the UK, the Central Electricity Generating Board made a $£ 150$ million bid for a share in the Ranger uranium project on native lands in Northern Territory in Australia. According to the Guardian, the CEGB bid is to safeguard Britain's growing need for uranium which is expected to incrase by $2 \frac{1}{2}$ times in the next 10 years.

\title{
Spanish scientists protest over looming cash crisis
}

Fifteen Spanish scientists last month published an open letter to their government. They claimed that research would be brought to a halt in 1980 if the government did not act quickly to provide funds. The letter, which appears below, was communicated to us by a Barcelona scientist, Dr Juan Subirana, whose further comments appear this week in correspondence (p 424). The scientists' difficulties appear against an annual inflation rate of $25 \%$, an extensive attempt to curb government expenditure, and a near-complete lack of scientific representation in parliament
State-financed research groups in Spain are in great difficulties for lack money - and if the government fails to take immediate action, their problems will be dramatically worse next year. On 31 December this year financial support for all projects approved by the Comision Asesora de Investigacion Cientifica $y$ Tecnica will end. The projects were

As you know, scientific and technical research in this country has three financial sources:

- Institutional finance through the universities, the council for scientific research (CSIC), and the research centres of ministries of agriculture, industry, health, public works, transport, and communications;

- Grants from Spanish or foreign foundations and those derived from bilaterial international agreements; and

- The Comision Asesora de Investigacion Cientifica y Tecnica (CAICT).

The first of these sources, instutitional finance, covers little more than maintenance, particularly in the case of the universities and the CSIC. Research funds come mostly from foundation and international grants and the CAICT. In the universities and the research centres of the CSIC at least $80 \%$ of the funds available for research come from the CAICT. Yet up to this date there has been no invitation from the Comision for proposals for new projects beyond the end of this year.

Since there are no substantial alternative sources, research - at least in the universities and the CSIC - will virtually cease on 1 January 1980.

The consequences are obvious: projects announced in 1975 and 1976. underway will have to be abandoned, in many cases with the loss of everything already achieved; and scientists in training and contracted auxiliary personnel will have to leave their laboratories.

The Comision Asesora was established in 1958. Recently it has come to belong to the Ministry of Universities and Research, with its annual budget of 1.1 billion pesetas ( $\$ 17$ million) dedicated to research. We understand that the Comision is being reorganised, but we do not understand why this reorganisation has halted the existing mechanisms for distributing Comision funds. We also understand that the government has prepared a three-year plan for research support which will be discussed in parliament, but it seems clear that no funds will be forthcoming from that plan until the second half of next year.

For the survival of science, we ask the government, through the Ministry of Universities and Research, to take urgent measures. We scientists signing below believe we speak as representatives of many others when we propose that the government should:

- Immediately announce the offer of Comision Asesora research grants for 1980 , and assure that the selection procedure is complete by the end of the year

- As a matter or urgency, put the threeyear plan for research before parliament.

So our country may have a minimum of independence and intellectual respect, political changes must go along with deep changes in our scientific and technological policy; but these changes must not be made at the expense of a temporary paralysation of Spanish research.
The day after this letter appeared in the Spanish press, a meeting of the joint council of the CSIC, the universities, and the Ministry of Universities and Research took place. The meeting had already been planned as part of the efforts to create a research policy for Spain. The press commented on 28 September:

El Pais (Madrid)

"The Ministry of Universities and Research is studying the reorganisation of the CSIC as one of the first steps in the redefinition of research supported by the administration. Among other measures there are the preparation of a general report on research in Spain, the three-year (1980-82) plan of research, cooperation with other administrative bodies, etc. In particular the remodelling of the Comision

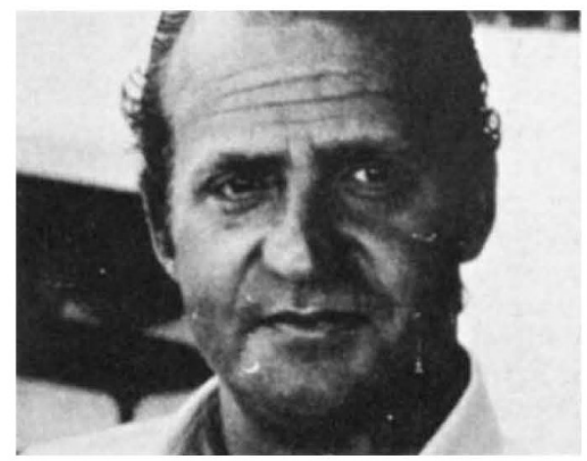

King Juan Carlos: trouble with science

Asesora de Investigacion Cientifica y Tecnica is also being considered.

"Publication appears imminent in the Boletin Oficial del Estado (the official government journal) of a decree that will approve the new bye-laws of the Comision, which is the advisory board of the government in scientific policy, and which has as a main mission the approval of research projects under government support and the distribution of funds to finance them." La Vanguardia (Barcelona)

"[The Comision Asesora has decided] not publicise now an annual announcement of projects, as requested by a group of scientists in a recent open letter to the Ministry of Universities and Research. The reason is that the 250 million pesetas ( $\$ 4$ million) available to the Comision would not solve the scientists' economic problems, while it seems more convenient to transfer this quantity to the next year and not to proceed with the announcement before January 1980'.

It thus appears that the situation of science in Spain is far from clear, and is continuing to give scientists considerable anxiety. 